DOI: $10.19195 / 0080-3626.62 .7$

EWA JABŁOŃSKA-STEFANOWICZ

\title{
AUTOR W ROLI WYDAWCY. KONIECZNOŚĆ CZY WYBÓR?
}

Współczesne możliwości samodzielnego publikowania. Vanity press (vanity publishing). Self-publishing. lishing

SŁOWA KLUCZOWE: autor, wydawca, samodzielne publikowanie, vanity press, self-pub-

,$[\ldots]$ in the long run it is the public which decides what the reward of authorship shall be [...]". „It will not become a best-seller just because it is put on a bookstall”.

S. Unwin, The truth about publishing

\section{WPROWADZENIE}

W tradycyjnym procesie wydawniczym podpisanie umowy z autorem oznacza, że wydawca uznaje jego dzieło za warte publikacji oraz że sprzedaż założonego nakładu gwarantuje osiągnięcie satysfakcjonującego zysku. Przyjęcie dzieła otwiera drogę do prac redakcyjnych, podczas których jest ono redagowane i projektowane. W podjęciu odpowiednich decyzji pomaga wydawcy znajomość oczekiwań i preferencji odbiorców, do których książka jest kierowana. Im wyższa okaże się wygenerowana w trakcie tych prac wartość dodana ${ }^{2}$, tym większe będą szanse na sprzedaż zaplanowanej liczby egzemplarzy.

Przy zwykle ograniczonych możliwościach manipulowania ceną wielkość rynku docelowego staje się najczęściej czynnikiem przesądzającym o losie własnych inicjatyw wydawnictwa, a także nadesłanych propozycji autorskich. Planowany przychód ze sprzedaży publikacji niskonakładowej może nie wystarczać

${ }^{1}$ Na dłuższą metę to publiczność decyduje, jaką nagrodę otrzyma autor. (Książka) nie stanie się bestsellerem tylko dlatego, że postawi sie ją na półce w księgarni (tłum. autorki).

${ }^{2}$ G. Clark, A. Phillips, Inside Book Publishing, London-New York 2014, s. 106-110. 
nawet na pokrycie kosztów jej produkcji, a wydrukowanie większej liczby egzemplarzy wydawca uznaje za zbyt ryzykowne. Istnieją jednak segmenty rynku, w których danym tytułem jest zainteresowanych niewiele osób, za to są one gotowe zaakceptować wyższą cenę jednostkową. Dotyczy to przede wszystkim segmentu książek fachowych, niezbędnych w pracy i rozwoju zawodowym niektórych specjalistów (na przykład prawników czy ekonomistów).

Innym rozwiązaniem jest $\mathrm{w}$ tej sytuacji próba obniżenia kosztów wydania tytułu (na przykład rezygnacja z bogatego wyposażenia edytorskiego); jeszcze innym - pokrycie tych kosztów (w całości lub w części) przez podmiot zainteresowany ukazaniem się danego tytułu na rynku. Dobrym przykładem jest tu sfinansowanie przekładu danej książki przez instytucje kulturalne macierzystego kraju autora. W podobny sposób działają wydawcy niskonakładowych książek lub czasopism akademickich, którzy starają się o dofinansowanie ze strony ośrodków naukowych (na przykład w postaci grantów przyznawanych autorom na badania lub publikację wyników).

Tytuły, do których wydania niezbędne są pieniądze pochodzące ze źródeł innych niż budżet wydawnictwa, określane są mianem ,wydawnictw subsydiowanych” (ang. subsidy publishing). Czasem stosuje się także pojęcie „wydawnictwa zlecone", podkreślając znaczenie instytucji współfinansującej publikację, która asygnując pieniądze, jednocześnie potwierdza jej wartość merytoryczną, a często współpracuje przy sprzedaży.

Osobną grupę wydawnictw subsydiowanych stanowią dzieła, które nie przeszły przez instytucjonalne sito wydawnicze i które autorzy zdecydowali się opublikować na własny koszt i ryzyko. Alison Baverstock zauważa, że do XVIII wieku powszechnie akceptowano konieczność poniesienia części kosztów przez nie dość jeszcze znanych pisarzy ${ }^{3}$. Wydawcy minimalizowali w ten sposób ryzyko, dzieląc się z autorami odpowiedzialnością za powodzenie przedsięwzięcia. Czasem jednak deklaracja pokrycia kosztów nie wystarczała. Na przykład ojcu Jane Austin nie udało się przekonać londyńskiego wydawcy ani argumentami literackimi, ani finansowymi i trzytomowa debiutancka powieść córki, w nowym kształcie i pod nowym tytułem (Pride and Prejudice), ukazała się dopiero 14 lat później. Z kolei powiastki dla dzieci autorstwa Beatrix Potter, z jej czarno-białymi ilustracjami, nie pasowały do estetyki obowiązującej na przełomie XIX i XX wieku, zostały więc opublikowane samodzielnie przez autorkę. Zdarzało się, że powód nieprzyjęcia dzieła był inny niż nierozpoznana czy nieakceptowana wartość artystyczna. Na przykład Ulisses należy do licznej grupy dzieł, które w pewnym czasie uznano za niemoralne i z tego powodu niekwalifikujące się do publikacji.

W polskim piśmiennictwie wnikliwą analizę aktywności autorów wydających dzieła własnym sumptem przeprowadziła Anna Gruca ${ }^{4}$. Zestawiła ona bazę

3 A. Baverstock, The Naked Author. A Guide to Self-publishing, London 2011, s. 41-42.

4 A. Gruca, Nakładem własnym... Autorzy jako wydawcy swoich prac w Krakowie w dobie autonomii galicyjskiej, Kraków 2007. 
blisko trzech tysięcy dzieł, które w opisie bibliograficznym w miejscu wydawcy mają nazwisko autora. Okazuje się, że stanowiły one ponad 16\% produkcji wydawniczej Krakowa w dobie autonomii galicyjskiej i w ogromnej większości wbrew obawom — nie były „rezultatem grafomańskich ambicji ich twórców”. W ten sposób publikowali wtedy zarówno uczeni - twórcy niskonakładowych książek naukowych, jak i spodziewający się wysokich zysków autorzy podręczników czy poradników. Wiele druków wydano z potrzeby skomentowania bieżących wydarzeń kulturalnych, politycznych czy społecznych.

Niniejszy artykuł poświęcony jest współczesnym możliwościom samodzielnego publikowania. Jego bohaterami są twórcy, którzy „skaczą przez płot” (ang. climb over the fence $)^{6}$, czyli rezygnują z tradycyjnej drogi nieuchronnie związanej $z$ oceną i selekcją dokonywaną przez komercyjnego wydawcę. Od niedawna mają oni alternatywę: zamiast książki drukowanej mogą samodzielnie opublikować e-booka.

Na rosnące znaczenie tego zjawiska jednoznacznie wskazują tendencje obserwowane w ostatnich latach na polskim rynku wydawniczym (tab. $1^{7}$ ):

- wzrost liczby zarejestrowanych podmiotów wydawniczych;

— wzrost liczby wydanych tytułów (w tym pierwszych wydań);

- spadek całkowitej produkcji wydawniczej;

— spadek średniego nakładu.

Tab. 1. Wybrane parametry opisujące zmiany na polskim rynku wydawniczym w latach 2011-2016

\begin{tabular}{|l|r|r|r|r|r|r|}
\hline \multicolumn{1}{|c|}{ Lata } & \multicolumn{1}{c|}{2011} & \multicolumn{1}{c|}{2012} & \multicolumn{1}{c|}{2013} & \multicolumn{1}{c|}{2014} & \multicolumn{1}{c|}{2015} & \multicolumn{1}{c|}{2016} \\
\hline Liczba nowych pul ISBN $^{8}$ & 2068 & 2176 & 2199 & 2359 & 2464 & 2464 \\
\hline Liczba tytułów $^{9}$ & 24920 & 27060 & 29710 & 32480 & 33490 & 36414 \\
\hline Liczba I wydań $^{10}$ & 12180 & 13408 & 15.300 & 18870 & 21130 & 23250 \\
\hline Średni nakład $^{11}$ & 4912 & 3987 & 3783 & 3236 & 2798 & 2435 \\
\hline Produkcja wydawnicza (mln egz.) $^{12}$ & 122,4 & 107,98 & 112,4 & 105,1 & 97,7 & 94,2 \\
\hline
\end{tabular}

Źródła danych: zob. przypisy 8-12.

${ }^{5}$ Ibidem, s. 183.

6 A. Baverstock, op. cit., s. 35.

7 Dane dotyczące produkcji wydawniczej pochodzą z badań przeprowadzonych przez Bibliotekę Analiz. Różnią się one od wyników opublikowanych przez Bibliotekę Narodową, a różnica wynika z przyjęcia różnych metodologii. Zob. Ł. Gołębiewski, P. Waszczyk, Rynek książki w Polsce. Wydawnictwa 2017, Warszawa 2017, s. 56, 59.

8 Sprawozdania Biblioteki Narodowej z lat 2011-2016, https://www.bn.org.pl/o-nas/sprawozdanie-bn [dostęp: 23.04.2019].

9 Ł. Gołębiewski, P. Waszczyk, op. cit., s. 57.

10 Ibidem.

11 Ibidem.

12 Ibidem, s. 58. 
Przybywa podmiotów wydawniczych (instytucjonalnych i prywatnych) pozyskujących numery ISBN na swoje publikacje, albowiem produkcja książek jest obecnie łatwa i tania. Szacuje się, że ci ,amatorzy-wydawcy”, funkcjonujący na uboczu głównego nurtu, odpowiadają za ponad 1/3 wydanych książek, zwykle okazjonalnych, niskonakładowych, rozpowszechnianych lokalnie ${ }^{13}$. To dlatego mimo wzrostu liczby tytułów, których coraz większą część stanowią pierwsze wydania, spada całkowita produkcja wydawnicza. Nieuchronnie prowadzi to do spadku średniego nakładu (poziom czytelnictwa utrzymuje się na niskim poziomie) i rentowności branży, dla której najbardziej opłacalne są przecież wznowienia. Rynek książki się zmienia: czynnikiem sprawczym stają się coraz częściej producenci treści (supply-side publishing), a nie — jak do tej pory — osoby zainteresowane ich zakupem i konsumpcją (demand-side publishing) ${ }^{14}$.

\section{VANITY PRESS (VANITY PUBLISHING)}

Na określenie firm, które na koszt autora opublikują dowolną książkę, stosujemy w niniejszej pracy angielski termin vanity ${ }^{15}$ press. Model biznesowy, na którym opierają one swoją działalność, polega na zaspokajaniu pragnienia twórcy, by ujrzeć swoje dzieło drukiem. Termin pojawił się w przestrzeni publicznej w latach 20.-30. XX wieku, choć zjawisko jest niewątpliwie starsze. W 1933 roku „Time” opisał praktyki wydawania poezji na koszt autorów, sięgające początku XX wieku, a w 1937 roku w artykułach „New Yorkera” przedstawiono postać Henry’ego Harrisona, który z autora finansującego publikacje swoich dzieł (jego pierwszą książkę ogłoszono „najgorszą książką kiedykolwiek wydaną"16) stał się wydawcą oferującym płatne usługi innym. Kilka lat później doszło do pierwszego procesu sądowego z vanity press $\mathrm{w}$ tle, którego przebieg szczegółowo relacjonował „New York Times". Carlo M. Flumiani został skazany na 18 miesięcy więzienia i 2,5 tys. dolarów grzywny za oszustwa na ogromną skalę, jakich dopuścił się wobec autorów zainteresowanych wydaniem swoich prac. Używając czterech pseudonimów i ośmiu starannie dobranych nazw nieistniejących firm wydawniczych (takich jak American Universities Press czy Associated Publishers of North America), pozorował działalność agencji szukającej dla danego tekstu odpowiedniego wydawcy, by w końcu obiecać fortunę tym, którzy zdecydują się na publikację za własne pie-

13 Ibidem, s. 37.

14 G. Clark, A. Phillips, op. cit., s. 4-5.

15 Vanity (ang.) — próżność.

16 T. Laquintano, The legacy of the vanity press and digital transition, „The Journal of Electronic Publishing" 16, 2013, nr 1, https://quod.lib.umich.edu/j/jep/3336451.0016.104?view=text;rg $\mathrm{n}=$ main\#N27-ptr1 [dostęp: 23.04.2019]. 
niądze w wydawnictwie o nazwie Fortuny ${ }^{17}$. Za korespondencję odpowiadał zespół zaangażowanych przez Flumianiego czterdziestu licealistów, którzy „przyjmowali” do 25 propozycji wydawniczych dziennie i prowadzili korespondencję z autorami, korzystając ze 146 wersji przygotowanych odpowiedzi. W zależności od sytuacji listy zawierały między innymi wyrazy uznania dla talentu twórcy, pochwałę wartości dzieła, obietnicę szybkiego wydania.

Proces Flumianiego ujawnił ogromne zapotrzebowanie na tego rodzaju usługi, równocześnie wskazując dwa filary, na których do dziś się one opierają: determinację autora do ujrzenia swego dzieła drukiem oraz wielkie rozczarowanie, jakie staje się udziałem twórcy po odrzuceniu jego tekstu przez profesjonalnego wydawcę ${ }^{18}$.

Opłata pobierana za wydanie książki obejmuje koszty związane z jej produkcją oraz zysk firmy. Jest on zwykle stały, natomiast koszty zależą od zakresu prac redakcyjnych i graficznych, na jakie zdecyduje się autor, oraz od wybranego kształtu poligraficznego książki (autor może się zdecydować na przykład na tańszą wersję i wybrać papier offsetowy i miękką oprawę zamiast papieru kredowego i oprawy twardej). Zależą one również od liczby egzemplarzy i sposobu dystrybucji publikacji, co także jest ustalane z autorem. Dlatego firmy typu vanity nie udostępniają najczęściej cennika świadczonych przez siebie usług, przygotowując na zamówienie kalkulacje konkretnych tytułów. Wniesienie opłaty jest zwykle jedynym warunkiem rozpoczęcia prac. To zasadnicza różnica między modelem działania takich firm a powszechnie znanym i akceptowanym sposobem wydawania książek drukiem przez tradycyjnego wydawcę, który publikuje tylko wybrane tytuły, nie pobierając od autorów żadnych opłat.

Literacką egzemplifikację działalności vanity press przedstawił Umberto Eco w powieści Wahadto Foucaulta ${ }^{19}$. Pan Garamond prowadzi dwa wydawnictwa, które różni wszystko: lokalizacja, wiek i uroda sekretarek, wyposażenie biura, tytuły i wygląd publikacji... Najważniejszą wszakże różnicą jest stosunek do autorów: w jednej oficynie kontakty z nimi są sporadyczne, a ich charakter w najlepszym razie neutralny; w drugiej zaś należą one do najważniejszych aktywności dyrektora. Spotyka się on $\mathrm{z}$ autorami nie tylko w swoim eleganckim gabinecie, lecz także w luksusowych restauracjach. W firmie określanej jako NWA (czyli Nakład Własny Autora) sprzedaje się bowiem nie książki, lecz szczęście. Metoda jest prosta. Na początku w lokalnych czasopismach pojawiają się regularnie zwięzłe informacje o nowych publikacjach, koniecznie z fotografiami twórców. To nie reklama, to sieć zastawiana na następnych. W oczekiwaniu na decyzję dotyczącą losu książek wysłanych do NWA ich autorzy są zapraszani na „wieczór gęsty

17 Slogan reklamowy listu zachęcającego autorów do publikacji brzmiał: „A Fortune to Gain in Each Fortuny Book", ibidem.

18 H.A. Sullivan, Vanity Press Publishing, https://www.ideals.illinois.edu/bitstream/handle/2142/5811/librarytrendsv7i11_opt.pdf?sequence=1, s. 113-114 [dostęp: 23.04.2019].

19 U. Eco, Wahadto Foucaulta, przeł. A. Szymanowski, Warszawa 1993. 
od przeżyć intelektualnych" 20 . Po nim ma miejsce pełna pochlebstw i manipulacji rozmowa, która prowadzi do podpisania umowy. Prawda, czyli informacja o sprzedaży niewielu egzemplarzy, przesłana autorowi wraz z łagodzącym ból zapewnieniem, że książka wyprzedza swój czas i dlatego zainteresowali się nią nieliczni, ujrzy światło dzienne dopiero za rok czy dwa. Cel zostaje osiągnięty. „Najważniejsze [...], żeby nie zawiedli nas autorzy, bez czytelników można się doskonale obejść" 21 — powiada pan Garamond.

Historia realnych firm, których działalność opiera się na produkcji książek na zlecenie, ryzyko i koszt autora, choć długa, nie obfituje w świadectwa i dokumenty. Firmy te starają się upodobnić do wydawców tradycyjnych, eksponując cechy wspólne i ukrywając różnice. Prawdziwą metodę ich funkcjonowania autor poznaje dopiero wtedy, gdy zdecyduje się skorzystać z usług którejś z nich. Często dobitniej niż wydawca przemawia opublikowana książka — jej jakość literacka, merytoryczna i edytorska jest zwykle niska, co pokazuje, że nie o uszanowanie gustów i oczekiwań czytelników tu chodzi.

W 2004 roku grupa amerykańskich pisarzy science-fiction i fantasy zorganizowała i przeprowadziła prowokację, której celem było wykazanie, że firma PublishAmerica - mimo deklaracji o odrzucaniu większości z nadesłanych propozycji i przyjmowaniu do druku wyłącznie dzieł wysokiej jakości — działa według modelu właściwego vanity publishing ${ }^{22}$. Powieść Atlanta Nights składała się z 41 numerowanych rozdziałów, wśród których dwa oparto na tym samym schemacie, dwa inne były identyczne, brakowało rozdziału 21, powtórzył się numer 12, a ,autorem” rozdziału 34 był komputer. Występujący w powieści bohaterowie zmieniali płeć i rasę, umierali i znów się pojawiali. Książka pełna była błędów ortograficznych i gramatycznych, nie przestrzegano także konsekwencji $\mathrm{w}$ formatowaniu tekstu. Jej autorzy zadbali natomiast, by początkowe litery imion bohaterów ułożyły się w hasło: „PublishAmerica is a vanity press”.

Mimo tych wszystkich uchybień powieść przyjęto do druku. Półtora miesiąca później mistyfikacja została ujawniona, a PublishAmerica „,po kolejnych recenzjach” wycofała się ze swojej poprzedniej decyzji. Mimo to książka została wydrukowana, jest dostępna w księgarni Amazon, a zyski ze sprzedaży zasilają fundusz pomocy medycznej dla pisarzy ${ }^{23}$. Opisaną historię znakomicie puentuje fragment recenzji T. Nielsen Hayden: „The world is full of bad books written by amateurs. But why settle for the merely regrettable? Atlanta Nights is a bad book written by experts"24.

20 Ibidem, s. 251.

21 Ibidem, s. 250.

22 Atlanta Nights, Wikipedia, https://en.wikipedia.org/wiki/Atlanta_Nights [dostęp: 23.04.2019].

23 Atlanta Nights, Amazon, https://www.amazon.com/Atlanta-Nights-Travis-Tea/dp/1411622 987/ref=sr_1_1?ie=UTF8\&qid=1522168350\&sr=8-1\&keywords=atlanta+nights [dostęp: 23.04.2019].

24 „Świat jest pełen złych książek napisanych przez amatorów. Ale po co poprzestawać na tym, co godne pożałowania? Atlanta Nights jest złą książką napisaną przez ekspertów" (tłum. autorki). 
Dekadę później podobnie skonstruowany test przeprowadził na polskim rynku wydawniczym Paweł Pollak ${ }^{25}$. Spreparowany tekst, czyli 10-stronicowy fragment rzekomo debiutanckiej powieści kryminalnej, który sam autor określił jako bełkot, trafił do dziewięciu „wydawnictw”. Niektóre poprosiły o przysłanie całości, inne zgłosiły zastrzeżenia dotyczące logiki zdarzeń czy rażących błędów, ale znalazły się też takie, które zadeklarowały szybkie wydanie książki na koszt autora i przysłały kalkulacje. Znalazły się w nich niejasne sformułowania, pomylone liczby i znacznie zawyżone, choć łatwe do weryfikacji (na przykład w wydawnictwach cyfrowych, które udostępniają kalkulatory online), koszty poligraficzne. W niektórych listach wysłanych autorowi znalazły się pochlebstwa i obietnice jakby żywcem wyjęte z przywołanej wcześniej powieści Eco.

Post, w którym Pollak opisał swoją przygodę z firmami vanity press, kończy gorzka refleksja:

Za dwie średnie krajowe można zostać w Polsce pisarzem [...] Umiejętność pisania nie jest potrzebna [...] tworzymy dowolny tekst, nie mając pojęcia o gramatyce i ortografii. Prawdopodobieństwem zdarzeń ani logiką nie musimy się przejmować. Akcja może być całkowicie pozbawiona sensu, nikt nie wymaga od nas, byśmy mieli coś mądrego do powiedzenia. [...] Jak nazywamy się Sobieski, to nasza książka stanie na półce w Bibliotece Narodowej niedaleko powieści Sienkiewicza $^{26}$.

Pollak zwraca uwagę na jeszcze istotniejszą rzecz: zgodnie z obowiązującym w Polsce prawem wprowadzanie kogoś w błąd w celu osiągnięcia korzyści majątkowej jest karalne.

Podstawowe zasady działania jednej z firm, do której trafił tekst Pollaka, opisał w rozmowie z „Biblioteką Analiz” jej właściciel ${ }^{27}$. Poligraf działa od 1992 roku, a od 2010 roku oferuje usługę wydania książki w całości za pieniądze autora. Jest to „kompleksowa usługa od a do z”: „podwójna korekta, w razie potrzeby również redakcja tekstu, indywidualny projekt okładki, skład i łamanie, czyli całe przygotowanie do druku, a także oczywiście druk i oprawa, a później również dystrybucja" 28 . Kosztuje to nie mniej niż 3,5 tys. złotych (jeden kolor, nakład 500 egz.). Od każdej sprzedanej książki autor otrzymuje „75\% wszystkich wpływów wydawnictwa", a te wynoszą połowę ceny detalicznej (druga połowa to marża dystrybutorów). W ten sposób Poligraf wydał już pół tysiąca tytułów. Strona internetowa firmy kusi autorów obietnicą sławy, uznania i szacunku ludzi, zbudowania pomnika trwalszego „niż ze spiżu”, zarobienia wielkich pieniędzy. Wraz z wydaniem książki „kariera wystrzeli w kosmos”, a autor (pisany zawsze wielką literą)

25 Paweł Pollak — o tym i owym, Pszygody komisaża Maciejewskiego, czyli jak wydawałem ze wspólfinansowaniem, http://pawelpollak.blogspot.com/2014/09/pszygody-komisaza-maciejewskiego-czyli.html. Obecnie blog jest dostępny tylko dla zaproszonych czytelników.

26 Ibidem.

27 Rozmowy o rynku książki, rozmowy przeprowadzili: Piotr Dobrołęcki, Łukasz Gołębiewski i Paweł Waszczyk, „Biblioteka Analiz”, Warszawa 2016, s. 46-48.

28 Ibidem, s. 46. 
zbuduje „swój autorytet eksperta i rozpoznawalność marki”. Błędy językowe, interpunkcyjne i edytorskie są obecne na każdej stronie serwisu, także w tekstach zamieszczonych w „elitarnym i pierwszym w kraju Klubie Pisarskim” ${ }^{29}$. Wydaje się, że już ta obserwacja wystarcza, by uznać Poligraf za firmę świadczącą za pieniądze usługę wydawniczą i nie pomylić jej z profesjonalnym wydawcą.

\section{SELF-PUBLISHING}

Dostępność technologii komputerowych umożliwiła powstanie serwisów internetowych, w których autorzy mogą samodzielnie opublikować swoje teksty. Trafiają one następnie do globalnej dystrybucji w postaci publikacji elektronicznych. Publikowanie tą metodą nie wiąże się z żadnymi obligatoryjnymi opłatami wstępnymi.

Usługi tego typu oferują największe księgarnie internetowe, na czele z amerykańskim Amazonem ${ }^{30}$. W Polsce popularność self-publishingu jest dalece mniejsza niż w Stanach Zjednoczonych czy nawet w Niemczech ${ }^{31}$, o czym świadczy zamknięcie najstarszych serwisów: Virtualo i Wydaje.pl. Do najprężniej działających należą obecnie RW2010.pl ${ }^{32}$ oraz E-bookowo ${ }^{33}$.

Do autora, który zdecyduje się w ten sposób opublikować swoje dzieło, należy zaakceptowanie regulaminu, przygotowanie tekstu zgodnie z podaną instrukcją i umieszczenie go w serwisie. Plik jest następnie bezpłatnie konwertowany do odpowiednich formatów (na przykład PDF, EPUB, MOBI) i udostępniany w postaci e-booka klientom internetowych księgarni. Zajmuje to od kilku godzin do kilku dni. Dostęp do panelu zarządzania tytułem umożliwia autorowi na przykład modyfikowanie treści i redagowanie tekstów reklamowych. Honorarium autorskie sięga nawet $70 \%$ ceny każdego sprzedanego pliku, przy czym cena ustalana jest na bardzo niskim poziomie (w księgarni Amazon jest to kilka dolarów, w Polsce kilka złotych; niektórzy autorzy decydują się na udostępnienie swoich publikacji bezpłatnie ${ }^{34}$ ). Proponowana umowa zwykle nie zawiera klauzuli wyłączności, autor może więc równolegle starać się o wydanie swego utworu w inny sposób.

29 Klub Pisarza.pl, http://klubpisarza.pl/ [dostęp: 23.04.2019].

30 Amazon, Take Control with Self Publishing, https://www.amazon.com/gp/seller-account/ $\mathrm{mm}$-summary-page.html/ref=footer_publishing?ld=AZFooterSelfPublish\& topic=200260520\&ie =UTF8 [dostęp: 5.12.2018].

31 Ł. Gołębiewski, P. Waszczyk, op. cit., s. 5.

32 RW2010, http://www.rw2010.pl/go.live.php/PL-H29/uslugi-dla-autorow.html [dostęp: 23.04.2019].

33 E-bookowo, https://www.e-bookowo.pl/ [dostęp: 23.04.2019].

34 D. Kudler, To Free or Not to Free: Giving Away Your Ebook, https://www.thebookdesigner. com/2018/04/to-free-or-not-to-free-giving-away-your-ebook/ [dostęp: 23.04.2019]. 
Decyzja o wyborze tej drogi publikowania powinna być decyzją podjętą świadomie, z pełną odpowiedzialnością za działania, które czekają self-publishera jako samodzielnego wydawcę. Oprócz napisania dzieła, czyli spełnienia obowiązków należących do pisarza, tekst trzeba zredagować, opracować typograficznie, złożyć i sprawdzić w procesie korekt. Należy też przygotować okładkę (czasem także materiały uzupełniające, jak tabele, rysunki, zdjęcia) oraz przemyśleć i zaplanować działania promocyjne. Nie wszyscy autorzy zdają sobie sprawę, że na sukces książki składa się praca wykonana przez wielu specjalistów zatrudnionych przez profesjonalnego wydawcę. Rezygnacja z ich usług wiąże się więc z koniecznością samodzielnego zadbania o wszystko.

Warto w tym miejscu przywołać artykuł Niny Amir o „kapeluszach”, które musi włożyć niezależny autor ${ }^{35}$. Najlepiej czuje się on prawdopodobnie w „kapeluszu twórcy unikatowych pomysłów na treść", która następnie przybiera kształt jednej lub kilku książek rozpowszechnianych z intencją zadowolenia wybranej grupy odbiorców. Podczas pisania, w zależności od wybranej tematyki, twórca nosi kolejne „kapelusze”, na przykład badacza lub detektywa. Następnie autor chce swoje publikacje sprzedać i na nich zarobić. W tym celu raz po raz zakłada „kapelusz przedsiębiorcy”, który realizuje pewien plan finansowy: analizuje rynek czytelniczy, szacuje liczbę osób zainteresowanych zakupem, wyznacza cenę książki, organizuje jej marketing, zmieniając „,kapelusz przedsiębiorcy” na przykład na „kapelusz blogera”. Teraz pora na przygotowanie tekstu do publikacji: samodzielnie albo - jeśli któryś z „kapeluszy” nie pasuje lub jego „noszenie” jest udręką - z pomocą specjalistów wynajętych do wykonania konkretnych czynności, na przykład redaktora, grafika czy korektora. W takiej sytuacji autor musi polubić „kapelusz menedżera”, który potrafi zarządzać większym zespołem. Ostatecznie wszystkie przymierzane i noszone „kapelusze” służą jednemu celowi: nabyciu i cieszeniu się „,kapeluszem autora, który odniósł sukces”.

Jak widać, w porównaniu ze zwyczajami panującymi w tradycyjnym wydawnictwie wpływ twórcy na rynkowy sukces samodzielnie wydanej książki może być ogromny. Od jego wiedzy, zaangażowania i kreatywności zależy prawie wszystko.

Jak powiedziano, znaczenie self-publishingu nie jest na razie duże, jednakże istnienie takiej alternatywy — darmowej i niezależnej od nikogo poza samym twórcą - może prowadzić do istotnych zmian na rynku książki. Warto podkreślić, że w przeciwieństwie do autorów zgłaszających się do firm vanity press po odrzuceniu ich tekstów przez profesjonalnego wydawcę, self-publishing bywa pierwszym wyborem. Autorem może tu zostać każdy, kto umie korzystać z komputerowych i internetowych narzędzi, ma coś ciekawego do powiedzenia i potrafi tym zainteresować innych. Całościowej oceny jego działań (autorskich, redakcyj-

35 N. Amir, The 3+ Hats Every Indie Author Must Wear, https://www.thebookdesigner.com/ 2015/04/the-3-hats-every-indie-author-must-wear/ [dostęp: 23.04.2019]. 
nych, graficznych i marketingowych) dokonują czytelnicy, podejmując decyzję o zakupie pliku. Znika bariera publikowania - self-publisher to autor niezależny (ang. independent writer, w skrócie: indie) od opinii i decyzji pracowników oficyn wydawniczych. Zdarza się jednak, że po sukcesie e-booka proponują oni autorowi podpisanie umowy na publikację drukowaną. Przykładem mogą być kariery Amandy Hocking ${ }^{36}$ czy — ostatnio - Rupi Kaur ${ }^{37}$, których samodzielnie opublikowane dzieła odniosły wielki sukces czytelniczy. Nie pozostał on niezauważony przez specjalistów z branży wydawniczej; następne tytuły tych autorek ukazały się już w komercyjnych oficynach.

\section{PODSUMOWANIE}

Autor, który chce wydać swoje dzieło, ma więc obecnie kilka możliwości:

— wysyła je do jednego lub kilku wydawców z nadzieją, że któryś dostrzeże $\mathrm{w}$ nim potencjał i zdecyduje się na inwestycję $\mathrm{w}$ jego opublikowanie $\mathrm{w}$ postaci książki;

— płaci za usługę wydawniczą: wydrukowanie książki (i ewentualnie jej dystrybucję);

— zamieszcza przygotowany samodzielnie plik z tekstem $\mathrm{w}$ serwisie self-publishingowym.

Sukces można mierzyć różnymi miarami. Jak wspomniano, sama decyzja o akceptacji tekstu przez znaną oficynę i włączeniu go do planu wydawniczego przydaje dziełu wartości. Problemem jest to, że tylko niewielka część nadesłanych propozycji spełnia wysokie wymagania wydawców — dotyczą one zarówno jakości tekstu, jak i wysokości planowanego nakładu. Pewność wydania oraz większą niezależność w kształtowaniu treści mają z kolei autorzy decydujący się na skorzystanie $\mathrm{z}$ dwóch innych możliwości: self-publishingu i vanity press. W obu wypadkach muszą jednak zadbać o publikację - przygotowanie tekstu i marketing — samodzielnie. Im lepiej rozumieją, na czym polega ciążąca na nich odpowiedzialność, tym większe prawdopodobieństwo sukcesu. Konieczność zapłaty za usługę może sprawić, że autor zwalnia się z obowiązku kontrolowania procesu wydawniczego, przenosząc odpowiedzialność na firmę wydawniczą, chętnie grającą rolę profesjonalisty. Zdecydowanie więcej jest przykładów na to, że twórcy, którzy zdecydowali się na niezależność, publikują dzieła samodzielnie, inwestując w ich jakość własny czas i pieniądze. Znakomitym przykładem jest tu Michał Sza-

\footnotetext{
36 Amanda Hocking, http://www.hockingbooks.com/ [dostęp: 23.04.2019].

37 Rupi Kaur, https://www.amazon.com/Rupi-Kaur/e/B0177TVPPU/ref=sr_tc_2_rm?qid= 1528108326\&sr=1-2-ent [dostęp: 23.04.2019].
} 
frański, który napisał książkę Finansowy ninja, samodzielnie ją wydał i sprzedał w ponad 60 tys. egzemplarzy ${ }^{38}$, rozmachem, pomysłami i zyskiem zawstydzając największe oficyny.

\section{BIBLIOGRAFIA}

Baverstock A., The Naked Author. A Guide to Self-publishing, London 2011.

Clark G., Phillips A., Inside Book Publishing, London-New York 2014.

Eco U., Wahadto Foucaulta, Warszawa 1993.

Gruca A., Nakładem własnym... Autorzy jako wydawcy swoich prac w Krakowie w dobie autonomii galicyjskiej, Kraków 2007.

Gołębiewski Ł., Waszczyk P., Rynek ksiażki w Polsce. Wydawnictwa 2017, Warszawa 2017.

Kudler D., To Free or Not to Free: Giving Away Your Ebook, https://www.thebookdesigner.com/ 2018/04/to-free-or-not-to-free-giving-away-your-ebook/.

Laquintano T., The legacy of the vanity press and digital transition, „The Journal of Electronic Publishing" 16, 2013, nr 1, https://quod.lib.umich.edu/j/jep/3336451.0016.104?view=text;rgn $=$ main\#N27-ptr1.

Sullivan H.A., Vanity Press Publishing, https://www.ideals.illinois.edu/bitstream/handle/2142/5811/ librarytrendsv7i11_opt.pdf?sequence $=1$.

\section{EWA JABŁOŃSKA-STEFANOWICZ}

\section{THE AUTHOR AS A PUBLISHER. A NECESSITY OR A CHOICE?}

\section{Summary}

The article is devoted to the possibilities authors have today to publish their works. They give up the traditional path, inevitably associated with judgement and selection carried out by a commercial publishers and opt for an alternative route: a vanity press (vanity publishing) or a self-publishing platform. Not so long ago it became possible to self-publish e-books alongside (or instead of) paper books. The growing significance of this phenomenon is unequivocally evidenced by the tendencies observed in recent years on the Polish book market: a rise in the number of registered publishing entities and number of published works (including first editions) as well as a decrease in the total output and average number of copies published. Self-publishing increasingly becomes a conscious choice: authors want to be sure that their works will be published, they want to have a bigger say in shaping its substantive and editorial form and - using their own ideas, time and money in publicity activities — to achieve fame and financial success.

KEY WORDS: author, publisher, vanity press, self-publishing

${ }^{38}$ Finansowy ninja, https://finansowyninja.pl/. Zob. też Jak robić duże pieniądze na self-publishingu i dlaczego e-booki musza być drogie - wyjaśnia Michat Szafrański, http://www.spidersweb.pl/2016/08/michal-szafranski-finansowy-ninja-wywiad.html; Michał Szafrański w pięć miesięcy zarobił na książce „Finansowy ninja” 880 tysięcy złotych, http://antyweb.pl/michal-szafranski-finansowy-ninja/ [dostęp: 23.04.2019]. 